\title{
Entrepreneurship Development Program in the Higher Education in Indonesia
}

\author{
Recky H.E.Sendouwa, Apeles L.Lonto, Sam J.R.Saroinsong
}

\begin{abstract}
Since 2012 University of Manado (Unima) collaborates with Humber Business School Canada to develop an applied entrepreneurship education program. This program aims to change the existing entrepreneurship curriculum at University of Manado which has tended to focus on the theory to be more applicative. In addition to changing the curriculum of entrepreneurship courses, a student entrepreneurship center called Unima Humber Entrepreneurship Center (UHEC) is also created that helps entrepreneurial students in extra-curricular form by providing training, seminars and incubation of entrepreneurship, mentoring and coaching clinic, also conducting marketplace or expo. In the period of 2017-2019 Unima received three years grant from Ministry of Research and Higher Education trough Entrepreneurship Development Program. By making use of qualitative approach, this study would like to analyze the impact of the program in the University of Manado. The results showed that more than 900 students applied to be the candidates of the Entrepreneurship Development Program training, 835 students involve in entrepreneurship expos, and 60 form 835 students elected as trainees and they are active in the Entrepreneurship Development training program. Twelve of 60 students now have been released from the business incubator and have been independent business start up. The conclusion of this research is Entrepreneurship Development Program have positive impact in Applied Entrepreneurship Development in Unima.
\end{abstract}

Index Terms: Entrepreneurship Development Program; Higher Education, University of Manado, Ministry of Research and Higher Education.

\section{INTRODUCTION}

Manado State University (Unima) in collaboration with the Humber Institute of Technology and Advanced Learning, Canada in the Sulawesi Economic Development Strategy (SEDS) Project which implements an applied entrepreneurship program as one aspect of the learning process. This project has been going on since 2012. Since 2013-2015 the Project has provided 6 times the facility for applied entrepreneurship workshops with a duration of around 360 working hours for 18 entrepreneurial lecturers and technical assistance in preparing applied entrepreneurship teaching books. After getting the workshop and compiling the module, in 2016 it was in the pilot project of giving Applied Entrepreneurship 1 and 2 courses in 2

\footnotetext{
Revised Manuscript Received on September 22, 2019.

Recky H.E.Sendouwa ,Public Administration Study Program, *Reckyhes@yahoo.com

Apeles L.Lonto, Department Pancasila and Civic Education

Sam J.R.Saroinsong ,Law Science Study Program Faculty of Social Sciences,Universitas Negeri Manado,Tondano City,North Sulawesi Province,Indonesia 95618,Universitas Negeri Manado.
}

consecutive semesters at 4 Faculties in 13 Study Programs in Manado State University with around 500 students taking this class (Sendouw, Kairupan, Mege, 2018).

Before this project takes place in Unima entrepreneurship courses are given in several faculties such as the Faculty of Economics, Faculty of Sport Sciences, Faculty of Mathematics and Natural Sciences and the Faculty of Engineering in one semester. However, because the teaching method is more focused on theory, the impact of this course to produce new entrepreneurs is almost invisible. Through this SEDS project entrepreneurship courses are given in 2 semesters in which the first semester is given in the form of theory and the second semester students are required to practice business planning and implement business ideas in the form of products that are ready for sale. At the end of the course a 2-day Entrepreneurship day event was created, the products and ready-to-sell ideas will be exhibited and presented to the judges and visitors. In collaboration with the Assistant Chancellor for Student Affairs, ideas and products that are quality and worth selling will be given funding capital from the Student Entrepreneurship Program (PMW).

The PMW program usually supports around 40-50 students each year by providing entrepreneurship training, encouraging the growth of motivation for entrepreneurship, increasing management understanding and making business plans or business feasibility studies up to the provision of working capital. The implementation of PMW activities with a pattern that currently applies in Unima, it turns out the success rate is very low. Until now there has been no record of the success of new tenants who still survive the PMW Program. This condition reflects that there are weaknesses in the process of methods of delivery of entrepreneurial learning, especially emphasizing the aspects of transfer of science and technology. Even though the potential of entrepreneurial students in Unima is currently quite large. This is evident since the implementation of applied entrepreneurship curriculum; more than 100 students have succeeded in making attractive and selling products even though it does need improvement in terms of product quality and packaging design. Product line of student works varies, consisting of snacks, t-shirts that are attractively designed, household accessories, equipment from recycled goods / used materials, ornamental plants to teaching materials, games, and on-line applications (Sendouw, Kairupan, Mege, 2018).

After going through the selection process to participate in entrepreneurial student programs, students under the guidance of UHEC must immediately strive to start up 


\section{Entrepreneurship Development Program in the Higher Education in Indonesia}

the business. However, the obstacles in the field at this time, it turns out that the applied entrepreneurship courses that have been given for 2 semesters have not been able to cover all the needs of students to start up business. Further training and coaching and continued monitoring are needed to reduce the risk of failure in entrepreneurship. Through Science and Technology for Entrepreneurship, students who have taken entrepreneurship courses and are serious about starting a business will be assisted with training, coaching and assistance in solving business problems they face, thus increasing the chances of success in business.

\section{LITERATURE REVIEW}

Some of the things that underlie the implementation of the Entrepreneurship Development program in Unima are:

Availability of employment is still a problem faced by college graduates. Many of those who are not absorbed in the workforce eventually become unemployed because they do not have entrepreneurial skills (Kourilsy and Walstad, 1998).

The Directorate General of Higher Education launched a student entrepreneurship program in 2009 to facilitate students interested in starting businesses in the fields of Science, Technology and the arts (Directorate General of Higher Education, Ministry of National Education, 2015)

Declaring the government through the Ministry of Cooperatives and SMEs to create 1 million new entrepreneurs in 5 years (2015-2020 RPJM) to reduce unemployment.

The Government's efforts to make Indonesia a developed country in 2045 (Indonesia gold). In various literatures, it is explained that one of the requirements to become a developed country is to have entrepreneurship at 2 percent of the population. When this program proposal was written in 2016, the percentage of entrepreneurs in Indonesia was less than 2 percent of the Total Population (Lanadalia, 2016).

Entrepreneurship is clearly one such type of academic program that can make links to socio-economic and ecological concerns and build applied skills to address them. Entrepreneurship education can be divided into two types: education about entrepreneurship and education for entrepreneurship (Fernando Lourenço, Taylor, \& Taylor, 2013). The former is largely theory driven while the latter equips students with the ability to become entrepreneurs. The latter requires an applied pedagogical approach that builds entrepreneurship skills where a process of 'doing' is central to the learning experience (Draycott \& Rae, 2011; F. Lourenço \& Jayawarna, 2011; Lourenço et al., 2013). An applied pedagogy does not, however, mean ignoring traditional teaching methods. Effective entrepreneurship education should make use of a mixed pedagogical approach that draws on both traditional and applied methods (Liñán \& Fayolle, 2015; Fernando Lourenço et al., 2013).

Entrepreneurship education refers to a collection of formalized teachings that inform, train and educate learners who are interested in setting up a business or small business development (Bechard \& Toulouse, 1998). Entrepreneurship education can be also be defined as skills that can be taught and the characUse the "Insert Citation" button to add citations to this document.

teristics that can be engendered to enable the individual to develop new and innovative plans (Jones \& English, 2004). While Yu Cheng, Sei Chan, \& Mahmood, 2009 mention that entrepreneurship education has traditionally been narrowly define as education that provides the needed skills to set up a new business and defined entrepreneur education as more than a business management or starting a new business. It is about "learning", learning that integrates experiences, skills and knowledge and the preparedness to start a new venture.

The importance of entrepreneurship education on the economic future of a nation has been much lauded by researchers, for example, Yu Cheng et al., 2009 and McKeown, Millman, Reddy Sursani, Smith, \& Martin, 2006. In their research, entrepreneurship education is more than creating a new business venture, but also denotes the understanding of the essence of entrepreneurship such as learning to be innovative, i.e., thinking out of the box, high readiness to change and being able to integrate and synthesize experience, skills and knowledge to create, innovate and evaluate abundant entrepreneurial opportunities they are trained to identify.

According to Yu Cheng et al., 2009, entrepreneurship education brings important returns to graduates and also to society in terms of encouraging the society as a whole to be more responsive towards new technology changes. In their research, Heinonen \& Poikkijoki, 2006 also report that entrepreneurial behavior is an innovative approach that constitutes a viable platform for economic development in any society.

\section{METHODOLOGY}

In this study, researchers used a qualitative research method which is a research method based on natural conditions with interpretive and constructive paradigms Because research is carried out under natural conditions, qualitative research methods can also be called naturalist research methods in which the collected data and analysis are qualitative. So, the research conducted is on natural objects, namely objects that develop as they are without being influenced by researchers including the dynamics of the object. In a qualitative research the researcher is the instrument, (Human Instrument). In order to obtain or obtain a broader and deeper understanding of the social situation to be examined. Qualitative methods are also used to get in-depth data, a fact that contains meaning. The meaning is actual data, definite data and is a value behind the visible data. Therefore, qualitative research is not emphasized that the results of the research must be generalized, but rather emphasize or prioritize the meaning.

In this study, more data analysis techniques were carried out together with data collection. The data analysis technique conducted in this study:

First, Data Reduction. The data obtained is recorded in the form of detailed descriptions which are then reduced to be selected only according to the focus of the problem under

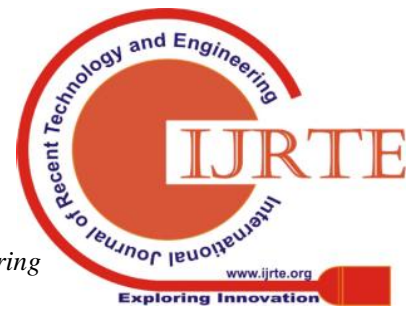


study. In conducting data reduction, it was carried out from the beginning to the end of the study.

Second. Data Presentation. After being reduced, the data resulting from the reduction is presented to make it easier to understand what is happening, then plan the next work based on what is understood.

Third, Data Verification. Verification is done from the beginning of the research until the research ends. It should be emphasized that based on the analysis of relevant data, the conclusions expressed at first (ongoing research) are still temporary and will change if there are no strong supporting evidence at the next data collection stage.

In carrying out qualitative data analysis, it can be done interactively and can last continuously until complete or the data is completely saturated. As for what is done in data analysis, among others: Data reduction, data presentation and conclusion or data verification.

\section{RESULTS AND FINDINGS}

The Entrepreneurship Development Program was implemented with a planning scheme designed in accordance with the conditions of the Manado State University. The design of the activities carried out in this program emphasizes the integration aspects of a program that starts with the selection of tenants through the process of recruitment with certain assessments until the supervision process for the implementation of activities while adhering to the program's output targets. The description of the planned implementation of the Entrepreneurship Development Program activities at UHEC Manado State University can be described as follows:

a. Pattern of Recruitment

The tenant recruitment in the KDP program will use an open pattern by targeting the right targets, namely entrepreneurship students guided by UHEC Unima. All tenant candidates will be reviewed by the Coach Team (lecturers who have attended workshops and applied entrepreneurship training) that will direct participants to become the core business in this activity.

\section{b. Approach Method}

The method of approach that will be carried out in this program certainly adjusts to the conditions of students who take part in the program.

Tenants who want to start for entrepreneurship, need a time to learn how to entrepreneurship through real experiences while preparing themselves to be able to compete in real business. This learning period is needed to change the perspective of business, explore interests (passion), the ability to observe business situations, establish business strategies, understand production processes, write business plans, learn to form relationships with fellow business partners and learn to deal with consumers and component suppliers later will deal intensively when they carry out real business activities. The process of bringing them closer to the real business system will be facilitated in the form of a business incubator. For tenants who are starting a business or have implemented a business, they will be given wider access to network creation, business management consulting, access to business credit, technology consulting, marketing facilitation, machinery and equipment, and participation in various business exhibitions.

The details of the steps to be carried out are as follows:

- Entrepreneurship training

Entrepreneurship training material will be delivered in the form of classes that are carried out as needed. Based on the type, this training will be divided into forms, namely:

1. Training by external instructors, the training to be carried out will further emphasize the motivational aspects of entrepreneurship through sharing experiences by several business practitioners.

2. Training by internal instructors, this training will present business experts from the Unima campus environment. The material presented will be more on the theoretical aspects and its implementation to the practical level.

The final stage of the training program will provide material to tenants about the content of business management that will soon be needed by tenants when they are involved in the real business world.

\section{- Coaching}

As a method of approach that will be carried out in guiding tenant businesses to be able to become sustainable entrepreneurs, the Entrepreneurship Development program at Manado State University will apply the Coaching method approach. The coaching method for business is a tenant business coaching program where the tenant as coachee seems to be apprenticing in his own business and gradually learns to implement business steps under the guidance of the coach.

\section{- Monitoring}

The monitoring process is carried out by accompanying lecturers through a mechanism of consultation and visitation to the business location. Consultation activities are conducted periodically and gradually, according to the guiding allocation for each accompanying lecturer. At this consultation stage, treatment differentiation is also carried out according to the stage of business undertaken, tenants who have been divided into groups will interact with the appointed lecturers according to the development stage of the business being carried out.

For tenants who have entered the implementation stage, this report will provide an overview of business activities that have been carried out by tenants as well as reports on the use of capital funds, both in recording ledgers and profit and loss statements and balance sheets. For tenants who are still in the stage of pioneering a business or idea, the report will contain the progress made and the stages of business preparation such as business vision and mission, market research, marketing plans, and others.

Some of the instruments used in supporting the monitoring process include: monthly reports, which contain financial reports, business developments or progress in a monthly period, problems, resolution efforts that have been made and various matters related to the ongoing

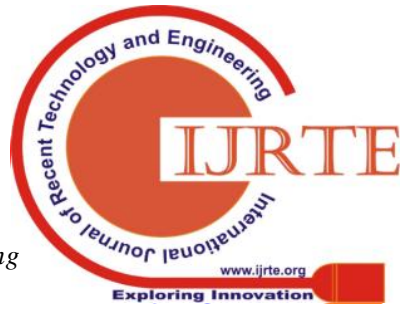




\section{Entrepreneurship Development Program in the Higher Education in Indonesia}

business process.

Based on these data, there will be recommendations for problem solving, or recommendations for actions to save tenant businesses. For each tenant, the accompanying lecturer who conducts the consultation will record the development of tenants in monitoring forms and recommendations for solving problems encountered by tenants. Visitation activities are conducted on a monthly basis for direct monitoring of tenant business developments as well as verification of business reports.

Method of Problem Solving

The pattern of settlement of problems faced by tenants will be carried out in the following stages:

1.Define the problem correctly. This definition includes the exact specifications of the initial state and the expected solution.

2. Analyze the problem and look for some appropriate problem-solving techniques.

3. Represent the knowledge needed to solve the problem.

4. Choose the best problem-solving technique

In essence, problem solving focuses on tenants, in accordance with the principle of the coaching method, namely the empowerment of tenants. So that in the process of solving the problem will actively involve tenants.

The function of coaching is basically to guide tenants to solve their own problems based on business principles. The accompanying lecturers do not act as mentors who provide solutions to problems, but guide tenants based on their experiences so that tenants will have more ability to solve problems even after the program is completed.

The Entrepreneurship Development Program with a combination of workshop, coaching, problem solving and exhibition methods is a program that was first held at Manado State University. Although it was only the first time it was implemented but it has shown quite impressive results. If there had never been any data regarding students taking part in entrepreneurship programs or students who had successfully opened tenants through this program. The advantage of implementing this program is that students get intensive training, guidance and assistance starting from the beginning of the implementation until they successfully start their own business (startup), open outlets independently. The gathering of students together with intensive assistance creates a synergistic and mutually supportive atmosphere so as to increase the enthusiasm of students to start a business. In addition, it is clear that these entrepreneurial students have increased discipline, perseverance and creativity and the ability to take risks into account. In addition, the desire to market their products forced them to open new friendship networks so as to increase social networking (Sendouw, at al., 2018).

The results showed that more than 900 students applied to be the candidates of the Entrepreneurship Development Program training, 835 students involve in entrepreneurship expos, and 60 form 835 students elected as trainees and the are active in the Entrepreneurship Development training program. Twelve of 60 students now have been released from the business incubator and have been independent business startup. The conclusion of this research is Entrepreneurship Development Program have positive impact in Applied Entrepreneurship Development in Unima.

The disadvantage of this program is that assistance is currently very much dependent on accompanying lecturers. The problem is that the lecturer has a variety of other activities, such as teaching, guiding students in study programs, conducting research and other activities. This is often an obstacle because when students need guidance, sometimes the accompanying lecturers cannot carry out their mentoring tasks because they conflict with other activities (Sendouw, at al., 2018).

The results of the Entrepreneurship Development Program in Unima showed that more than 900 students applied to be the candidates of the Entrepreneurship Development Program training, 835 students involve in entrepreneurship expos, and 60 form 835 students elected as trainees and they are active in the Entrepreneurship Development training program. Twelve of 60 students now have been released from the business incubator and have been independent business startup.

In addition, it was seen that there was a change in character of students in the Entrepreneurship Development Program, because they became more respectful of time, diligent in carrying out their business, becoming more creative, having wider relationships and having the courage to take risks.

\section{CONCLUSION}

In accordance with the description described above, it can be concluded that the Entrepreneurship Development Program at Manado State University runs well and in accordance with the stages planned. The existence of this program increases the enthusiasm of students in conducting entrepreneurial activities starting from taking part in entrepreneurship courses, making business proposals, preparing products to participating in entrepreneurial exhibitions and product sales. The obstacle faced in this Entrepreneurship program is the other busyness of the accompanying lecturers which causes them to be unable to accompany entrepreneurial students in full.

The Entrepreneurship Development Program with a combination of workshops and mentoring methods and exhibitions at Unima had a very significant impact. At present there are so many enthusiastic students participating in the entrepreneurship program at UHEC Unima.

In addition, it was seen that there was a change in character of students in the Entrepreneurship Development Program, because they became more respectful of time, diligent in carrying out their business, becoming more creative, having wider relationships and having the courage to take risks. 


\section{ACKNOWLEDGEMENT}

This research work is supported by the Entrepreneurship Development Program 2019 grant, Hibah Pengabdian kepada Masyarakat Program Pengembangan Kewirausahaan (PPK) 2019, Directorate Research and Community Development, Ministry of Research Technology and Higher Education Republic of Indonesia

\section{REFERENCES}

[1] Bechard, J.-P., \& Toulouse, J.-M. (1998). Validation of a didactic model for the analysis of training objectives in entrepreneurship. Journal of Business Venturing, 13(4), 317-332. https://doi.org/10.1016/S0883-9026(98)80006-2

[2] Chen, C. C., Greene, P. G., \& Crick, A. (1998). Does entrepreneurial self-efficacy distinguish entrepreneurs from managers? Journal of Business Venturing, 13(4), 295-316. https://doi.org/10.1016/S0883-9026(97)00029-3

[3] Direktorat Jenderal Pembelajaran Dan Kemahasiswaan Kementerian Riset, Teknologi, Dan Pendidikan Tinggi. 2015, Pedoman Program Mahasiswa Wirausaha (Pmw) Tahun 2015 https://belmawa.ristekdikti.go.id/dev/wp-content/uploads/2015/11/6.-Pe doman-PMW-2015.pdf

[4] Direktorat Riset dan Pengabdian Masyarakat Direktorat Jenderal Penguatan Riset dan Pengembangan Kementerian Riset, Teknologi, dan Pendidikan Tinggi, 2018. Pedoman Penelitian dan Pengabdian Kepada Masyarakan, Edis

http://simlitabmas.ristekdikti.go.id/unduh_berkas/Buku\%20Panduan\%2 0Pelaksanaan $\% 20$ Penelitian $\% 20$ dan $\% 20$ Pengabdian $\% 20$ kepada $\% 20 \mathrm{M}$ asyarakat\%20Edisi\%20XII.pdf

[5] Draycott, M., \& Rae, D. (2011). Enterprise education in schools and the role of competency frameworks. International Journal of Entrepreneurial Behavior \& Research, 17(2), 127-145 https://doi.org/10.1108/13552551111114905

[6]

[7] Fitzsimmons, J. R., Douglas, E. J., Antoncic, B., \& Hisrich, R. D. (2005). Intrapreneurship in Australian firms. Journal of Management and Organization, 11(1), 17-27. https://doi.org/10.5172/jmo.2005.11.1.17

[8] Hegarty, C. (2006). It's not an exact science: teaching entrepreneurship in Northern Ireland. Education + Training, 48(5), 322-335. https://doi.org/10.1108/00400910610677036

[9] Heinonen, J., \& Poikkijoki, S. (2006). An entrepreneurial-directed approach to entrepreneurship education: mission impossible? Journal of Management Development, 25(1), 80-94. https://doi.org/10.1108/02621710610637981

[10] Jones, C. (2010). Entrepreneurship education: revisiting our role and its purpose. Journal of Small Business and Enterprise Development, 17(4), 500-513. https://doi.org/10.1108/14626001011088697

[11] Jones, C., \& English, J. (2004). A contemporary approach to entrepreneurship education. Education + Training, 46(8/9), 416-423. https://doi.org/10.1108/00400910410569533

[12] Kolvereid, L., \& Moen, Ø. (1997). Entrepreneurship among business graduates: does a major in entrepreneurship make a difference? Journal of European Industrial Training, 21(4), 154-160. https://doi.org/10.1108/03090599710171404

[13] Kourilsy, M. L. Walstad, W. B. (1998) Entrepreneurship Female and youth: Knowledge, Attitude, gender differences, and Practices. Journal of Business Venturing. 13(1), 77-88.

[14] Lahandalia, B. (2016) Jumlah Pengusaha di Indonesia baru 1.5 Persen dari Total Penduduk. Tersedia dari https://m.suara.com/bisnis/2016/05/09.

[15] Liñán, F., \& Fayolle, A. (2015). A systematic literature review on entrepreneurial intentions: citation, thematic analyses, and research agenda. International Entrepreneurship and Management Journal, 11(4), 907-933. https://doi.org/10.1007/s11365-015-0356-5

[16] Lourenço, F., \& Jayawarna, D. (2011). Enterprise education: The effect of creativity on training outcomes. International Journal of Entrepreneurial Behaviour \& Research, 17(3), 224-244. https://doi.org/10.1108/13552551111130691

[17] Lourenço, F., Taylor, T. G., \& Taylor, D. W. (2013). Integrating "education for entrepreneurship" in multiple faculties in "half-the-time" to enhance graduate entrepreneurship. Journal of Small Business and Enterprise Development, 20(3), 503-525. https://doi.org/10.1108/JSBED-04-2013-0052

[18] McKeown, J., Millman, C., Reddy Sursani, S., Smith, K., \& Martin, L. M. (2006). Graduate entrepreneurship education in the United Kingdom.

\section{Education $\quad+\quad$ Training, 48(8/9), https://doi.org/10.1108/00400910610710038}

[19] Nabi, G., Walmsley, A., Liñán, F., Akhtar, I., \& Neame, C. (2016). Does entrepreneurship education in the first year of higher education develop entrepreneurial intentions? The role of learning and inspiration. Studies in Higher Education, pp. 1-16. https://doi.org/10.1080/03075079.2016.1177716

[20] Sendouw, R H E, Sisca B. Kairupan, Revolson A. Mege. (2018). Applied Entrepreneurship Education at University of Manado North Sulawesi Indonesia. International Journal of Engineering \& Technology. 7(3.25) (2018)

282-285. https://www.sciencepubco.com/index.php/ijet/article/view/17582

[21] Sendouw, R. H. E., Revolson A. Mege, Jeane Tuilan, Jeane Mantiri.(2018). Ipteks Bagi Mahasiswa Kewirausahaan Di Universitas Negeri Manado. Majalah Aplikasi Ipteks NGAYAH 9 (1), 138-147, http://e-journal.unmas.ac.id/index.php/ngayah/article/view/21/18

[22] World Bank. (2016). UKM yang dimiliki Wanita di Indonesia: Kesempatan Emas untuk Institusi Keuangan Lokal. http://documents.worldbank.org/curated/en/737221477568795492/pdf/ 109534-WP-BAHASA-SME-Indonesia-Final-Ind-PUBLIC.pdf

[23] Yu Cheng, M., Sei Chan, W., \& Mahmood, A. (2009). The effectiveness of entrepreneurship education in Malaysia. Education + Training, 51(7) 555-566. https://doi.org/10.1108/00400910910992754

[24] Zimmerer, T. W., Scaborough, N. M., Wilson, D. (2008) Essentials of entrepreneurship and small business management (5Th Edition). Diterjemahkan oleh Kwary D. A. dan D. Fitriasari. Kewirausahaan dan Manajemen Usaha Kecil. Jakarta: Salemba Empat. 